NBER WORKING PAPER SERIES

\title{
THE ROLE OF PROXIMITY IN FORECLOSURE EXTERNALITIES: EVIDENCE FROM CONDOMINIUMS
}

\author{
Lynn M. Fisher \\ Lauren Lambie-Hanson \\ Paul S. Willen \\ Working Paper 20080 \\ http://www.nber.org/papers/w20080
NATIONAL BUREAU OF ECONOMIC RESEARCH
1050 Massachusetts Avenue
Cambridge, MA 02138
April 2014

The authors thank Douglas Errico, Chris Foote, Kris Gerardi, Tim Lambie-Hanson, Anthony PenningtonCross, Jonathan Spader, BillWheaton, and audiences at the American Real Estate and Urban Economics Association, the Association for Public Policy Analysis and Management, the Federal Reserve Bank of Boston's New England Study Group, and the University of North Carolina at Charlotte for helpful comments and suggestions. Suzanne Lorant and Jamie Fogel provided excellent editorial assistance. The views expressed here are solely those of the authors, not necessarily those of the Federal Reserve Bank of Boston, the Federal Reserve Bank of Philadelphia, the Federal Reserve System, or the National Bureau of Economic Research. Lauren Lambie-Hanson received a dissertation grant from the Lincoln Institute of Land Policy, which helped support this research.

NBER working papers are circulated for discussion and comment purposes. They have not been peerreviewed or been subject to the review by the NBER Board of Directors that accompanies official NBER publications.

(C) 2014 by Lynn M. Fisher, Lauren Lambie-Hanson, and Paul S. Willen. All rights reserved. Short sections of text, not to exceed two paragraphs, may be quoted without explicit permission provided that full credit, including (C) notice, is given to the source. 
The Role of Proximity in Foreclosure Externalities: Evidence from Condominiums

Lynn M. Fisher, Lauren Lambie-Hanson, and Paul S. Willen

NBER Working Paper No. 20080

April 2014

JEL No. G12,R3

\section{ABSTRACT}

We measure the effect of foreclosures on the sale prices of nearby properties using a dataset of condominiums in Boston. A foreclosure in the same association and at the same address depresses the sale price by 2.5 percent, but properties in the same association but located at a different address have an effect that is tightly estimated at zero. Since properties in the same association are close substitutes, we argue that the evidence points against the pecuniary externality of property coming on the market and toward a physical externality as the source of measured foreclosure externalities.

Lynn M. Fisher

University of North Carolina

Chapel Hill, NC

lynn_fisher@unc.edu

Lauren Lambie-Hanson

Federal Reserve Bank of Philadelphia

10 Independence Mall

Philadelphia, PA 19106

1slambiehanson@alum.mit.edu
Paul S. Willen

Federal Reserve Bank of Boston

600 Atlantic Avenue

Boston, MA 02210-2204

and NBER

willen968@gmail.com 
Starting with Immergluck and Smith (2006), researchers have documented that properties that sell near foreclosures transact at a discount relative to otherwise identical properties that have no foreclosures nearby. We extend this literature by focusing on a sample of Boston condominiums that helps us to identify the mechanism that generates these price effects. In particular, we aim to distinguish between two popular theories, the first being that foreclosures cause price declines through a "supply effect," resulting from the fact that a foreclosed property is a close substitute for nearby properties. An alternative and not mutually exclusive explanation is that an owner has no incentive to invest in his property during the foreclosure process, and so the property deteriorates, generating a physical externality. Our results have important implications for policy. If foreclosures affect prices merely by increasing the supply on the market, then the effect of foreclosures on nearby properties is a pecuniary externality, implying that the market outcome is not necessarily inefficient and that government intervention risks choosing winners and losers rather than increasing overall welfare. In contrast, a physical externality always allows for welfare-improving policy interventions.

In this paper we shed light on these different explanations of the effect of foreclosures on neighboring properties using a dataset of condominium transactions in Boston over the years 1987 to 2012. Condominiums provide a natural laboratory to study the effects of foreclosures on neighboring properties because, especially with large associations, they provide a relatively large sample of highly substitutable homes. What makes our data particularly useful is that we can identify membership in condominium associations. Specifically, our data allow us to distinguish between three types of nearby condo foreclosures: same-association, same-address (SASA); same-association, differentaddress (SADA); and nearby $(<0.1$ miles) different-association, differentaddress (DADA) units. Our main finding is that SASA foreclosures have an economically and statistically significant effect on the sale prices of nearby properties with each foreclosure depressing prices by 2.5 percent, as shown in Panel A of Table 1. But an almost more striking finding is that SADA foreclosures in large associations have no effect at all: as Table 1 shows, the 
coefficient on SADA foreclosures is tightly estimated near zero.

To demonstrate how our quantitative findings help us to understand why foreclosures depress prices, consider our alternative hypotheses. If foreclosures drive down prices because they add supply to the market - the pecuniary externality - we would expect association to matter more than location within the association. The reason is that condos in the same association are typically very close substitutes for one another, with similar and often identical floorplans, finishes, and appliances, and they often share amenities like health clubs and swimming pools. If the pecuniary externality were the driving force, we would expect SASA and SADA foreclosure to have a similar effect. On the other hand, if the effect on prices is a physical externality, we would expect distance to matter more, with SASA foreclosures mattering more than SADA. Indeed, this is what we find.

Because we are studying condominiums, we must pay special attention to a public goods problem that emerges when home ownership is at least partially shared: the owner of a condo in mortgage foreclosure has little incentive to make association payments. Failure to pay these fees leads to depleted reserves, deferred maintenance, or increased fees on remaining homeowners, and any of these scenarios will make a building and association less desirable to prospective buyers. Thus, in addition to the physical and pecuniary externalities, condo foreclosures create a public goods problem which could also put downward pressure on prices within an association. Can we distinguish between this public goods externality and the other types? For large associations $(51+$ units $)$, which account for about two-thirds of sales with same-association foreclosures, the answer is yes. Anything that affects an association as a whole should affect all properties regardless of whether they are located at the same address or a different address. In other words, if the effects we observe are driven by the public goods problem, we should see equally large coefficients on SASA and SADA foreclosures. On the other hand, if there is no public goods problem, we should see SADA foreclosures generating no discount, which is what we find. For medium-sized associations (13-50 units), the results are more nuanced. The point estimate on SADA foreclosures is economically 
meaningful but not statistically different from zero. Thus public goods issue could explain at least some of the discount in smaller associations.

To interpret these results, we turn to a Massachusetts law passed in 1992 to deal with the problem of unpaid dues. The law resulted from a wave of condo foreclosures in the early 1990s that led to the failure of entire associations: when a critical number of owners stopped paying dues, associations could no longer finance a minimum level of services. To deal with this, the state allowed associations to place a lien on properties to collect unpaid association fees. Since the law gave the association lien priority over all existing liens including the mortgage, it is known as the "super-lien" law. For two reasons, the superlien law disproportionately benefits large associations. First, an association needs to have access to legal counsel to enforce the priority lien, and large, professionally managed associations are much more likely to have such access and to coordinate legal actions in a timely manner. But second, practically speaking, a professional manager who gets reimbursed for any services he or she provides has a strong incentive to maintain a high level of service, since association income required to pay managers is assured. (Once notification of the intent to enforce the priority lien has been made to first mortgage lenders, these lenders tend to take over payment of association fees for delinquent owners in order to preserve the priority of their mortgage.) With this in mind, the results in Table 1 make sense. For large associations, the superlien law inoculates the association from the public goods problem and only physical externalities matter. For medium-sized associations, the superlien law is less effective, and the measured effect on SASA properties is some combination of the public goods problem and the physical externality.

Our results provide a different perspective on the foreclosure externality problem. Previous researchers identified the substitutability of properties largely by distance. To interpret the finding that a property one-tenth of mile away had a bigger effect on prices than a property one-quarter of a mile away as evidence of a pecuniary externality, one has to assume that a property one-tenth of a mile away is a closer substitute than a property one-quarter of a mile away. There are two problems with this approach. First, a physical 
externality will also generate the same pricing pattern, as the physical externality deteriorates with distance from the foreclosed property. But the second problem is that, for the typical buyer, such small differences in location play only a small role in a valuation decision. A physically identical property a mile or even further away might be a much closer substitute than a property on the same street. In a sense, our dataset allows us to hold substitutability constant within a condo association and vary distance in order to identify differences previously clouded by the data.

We argue above that the logical explanation for the effect of distance within condo associations is a physical externality, but one natural question here is how that physical externality works. How does poor maintenance of a unit affect neighbors at the same address but not neighbors at a different address when the buildings are all jointly administered? To gain some insight, in Section 4 we turn to records from the City of Boston on constituent complaints to City government agencies, as compiled in Lambie-Hanson (2013). We find that many buildings with foreclosures have had complaints reported about property conditions, and these complaints sometimes specifically reference problems like pest infestation that originate in one unit but subsequently impact neighbors in the same building.

Our results are consistent with earlier work. Campbell, Giglio, and Pathak (2011) use the same dataset that we do and, indeed, find evidence of foreclosure externalities only for condominiums and not for single-family or small multifamily properties. For their entire sample, Anenberg and Kung (2013) find that foreclosures exert an effect on prices only after the properties become bank owned and are listed for sale, a finding they argue is evidence against a physical externality. But for their "high-density" subsample, which most closely corresponds to our sample, they find strong effects prior to the foreclosure auction sale, which they attribute, as we do, to a physical externality.

Ours is not the first research to draw significant conclusions from the Boston condominium market. Genesove and Mayer (1997) and Genesove and Mayer (2001) used data from the same Boston condominium properties to argue for the role of loss aversion and leverage, respectively, in homeowners' sale 
decisions. As mentioned above, Campbell, Giglio, and Pathak (2011) use the same dataset we do, and although their regressions include all properties in Massachusetts, their main findings relate to condominiums, a large share of which are located in Boston.

In the following sections, we describe our model of house price changes, discuss our data and results, and consider the possible implications of our findings.

\section{Estimation Strategy}

To measure the external effects of foreclosures, nearly all researchers to date have used some version of the following spatial externality regression:

$$
\ln \left(P_{i t}\right)=\beta \mathbf{X}_{i t}+\gamma N F_{i t}+e_{i t},
$$

where $P_{i t}$ is the sale price of property $i$ in period $t, X_{i t}$ is a vector of property characteristics, $N F_{i t}$ is the number of nearby foreclosures within a certain geographic radius of the property occurring in a particular time window around the sale, and $e_{i t}$ is a property $\times$ date-of-sale-specific error term. ${ }^{1}$ Prominent examples of research along these lines include Immergluck and Smith (2006); Schuetz, Been, and Ellen (2008); Harding, Rosenblatt, and Yao (2009); Campbell, Giglio, and Pathak (2011); and Gerardi et al. (2012). ${ }^{2}$

There are several challenges in estimating equation (1). The first problem arises from the causal relationship between $P$ and $N F$ - negative equity causes foreclosure - which leads to a negative value for $\gamma$ even when there is no spatial effect of foreclosures on prices. To see why, imagine that a demand shock hits one neighborhood in a metropolitan statistical area (MSA), and the shock leads to a fall in prices relative to other MSAs and a consequent relative

\footnotetext{
${ }^{1}$ For a thorough discussion of the literature on strategies for modeling foreclosure spillovers on house prices, see Gerardi et al. (2012) and Frame (2010).

${ }^{2}$ Rossi-Hansberg, Sarte, and Owens III (2010) is one of the few papers in the literature on spatial externalities that uses a different approach, calculating a price function for all properties regardless of whether a transaction occurs.
} 
increase in foreclosures and higher relative density of foreclosures. Higher foreclosure density, in turn, implies that foreclosures are more likely in any geographic radius in the neighborhood in question, meaning that in an MSAlevel regression we will find a correlation between price declines and nearby foreclosures regardless of whether there actually is a causal relationship.

To address the reverse causality problem we introduce a full set of time $\times$ census tract dummies in equation (1). ${ }^{3}$ This means that $\gamma$ in our models reflects a comparison of two properties in the same tract that differ with respect to the number of foreclosures that occur nearby. ${ }^{4}$ In other words, since we are not comparing properties in different census tracts, our identification would only be confounded if some shock generated different within-census-tract trends in house prices and foreclosures.

The second problem is the enormous heterogeneity of residential properties. Systematic differences between properties with foreclosures nearby and properties without foreclosures nearby would bias our estimates of $\gamma$. For example, if properties near a foreclosure are older, less well maintained, or less likely to have high-end features like jacuzzi tubs, granite countertops, or ocean views, we would tend to overestimate the negative effect of foreclosures on prices. Hedonic regressions control for these characteristics but leave two problems unsolved. The first is that the $\beta \mathrm{s}$, the relationships between prices and characteristics, may not be stable across time or locations. The second, more serious, problem is that hedonic models can only control for observable variation, and the set of observables in tax assessor's data is limited and plagued by measurement issues. Poor maintenance simply is not measured at all, and even basic variables, like the number of bedrooms, are subject to the judgement of the assessor.

\footnotetext{
${ }^{3}$ We follow Bailey, Muth, and Nourse (1963) and code tract-year dummies as -1 in the year of the first sale and +1 in the year of the second sale in the pair of arm's-length transactions. For simplicity, we refer to these as the "purchase" and "sale," though the time between two arm's-length transactions may span multiple ownerships.

${ }^{4}$ Our data allow us to use much finer geographic controls - down to the census blockbut Gerardi et al. (2012) show that the benefits of going below the tract level are minimal. Table 5 shows sensitivity results that demonstrate that our findings do not differ materially when we use block group instead of tract controls.
} 
To address the heterogeneity problem, we use a repeat-sales approach, looking at the price difference between two sales of a property. To understand our specification, assume that we can decompose the error term $e_{i t}$ into three components:

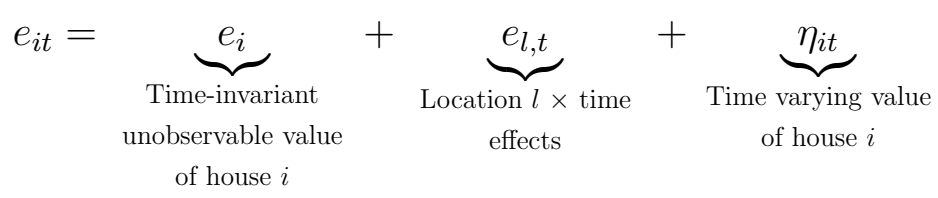

If we substitute equation (2) into equation (1) and take the difference between the sale $(s)$ and purchase $(p)$ we get:

$$
\begin{aligned}
& \ln \left(P_{i, \text { sale }}\right)-\ln \left(P_{i, \text { purchase }}\right)=\beta\left(\mathbf{X}_{i, \text { sale }}-\mathbf{X}_{i, \text { purchase }}\right)+ \\
& \gamma\left(N F_{i \text { sale }}-N F_{i, \text { purchase }}\right)+e_{l, \text { sale }}-e_{l, \text { purchase }}+\varepsilon_{i},
\end{aligned}
$$

where $\varepsilon_{i}=\eta_{i, \text { sale }}-\eta_{i \text {,purchase }}$ is a property-ownership-specific error term.

We stress three key points about equation (3). First, differencing removes the time invariant unobservable heterogeneity $e_{i}$. In other words, if houses next to railroad tracks sell at a discount because of the noise, and borrowers in those houses tend to default more, we will not attribute the price discount to the foreclosures. Second, since the observable characteristics $X_{i, t}$ do not change much, $X_{i \text {,sale }}-X_{i \text {,purchase }}$ is almost always zero, and the instability of $\beta$ across locations or time presents only a minor problem.

Finally, equation (3) illustrates both the reverse causality problem and our solution. A demand shock that reduces prices and causes foreclosures will lead to a correlation between the error term $\varepsilon_{i}$ and $N F_{i \text {,sale }}-N F_{i \text {,purchase. By }}$ introducing the purchase and sale year by location dummies, the error term now only picks up within-location variation in price changes across properties.

Gerardi et al. (2012) show that the presence of nearby distressed properties is associated with lower sale prices, starting when the borrower becomes seriously delinquent and ending a year after the sale of the lender-owned foreclosed properties known as "real estate owned" (or REO) in the industry. Since we 
do not have detailed delinquency information in our dataset, we approximate such information by considering a foreclosure to be "active" during a window of time that starts one year prior to the foreclosure auction (to accommodate the period when the borrower is seriously delinquent) and ends two years after the auction (to account for the time the property is marketed and sold by the lender, as well as the time when it is initially held by a third-party owner after exiting REO).

This approximation fits well with what we know about the foreclosure process in Boston. During 2007, the median time from the last foreclosure petition to the foreclosure deed was 192 days, and in 2012 it was 310. In our sample, over 80 percent of foreclosures become REO, and for REO resales, the median time was 153 days in 2007 and 285 days in 2012. Below we test the robustness of our results to the use of alternative windows of time. ${ }^{5}$

With some notable exceptions, all researchers in this literature have limited their attention to single-family residential (SFR) properties. The logic for focusing on SFRs is that these are the most common type of housing, particularly outside large cities, and that both condominiums and multifamily properties pose complications for modeling prices. Campbell, Giglio, and Pathak (2011) make the most prominent break with this tradition by including not only SFRs but also condominiums and small multifamily properties in their main sample. ${ }^{6}$ As mentioned in our introduction, Campbell, Giglio, and Pathak (2011) find that the condo sample is the only one in which foreclosure externalities play an economically or statistically meaningful role. They do not, however, explicitly model the effect of condominium foreclosures, for

\footnotetext{
${ }^{5}$ Campbell, Giglio, and Pathak (2011) use the difference between the sale prices of properties that sell in the year after versus the year before the arm's-length sale, but Gerardi et al. (2012) argue that the CGP approach biases researchers against finding an effect of foreclosures on prices.

${ }^{6}$ Hartley (2011) distinguishes between the impacts of single-family and multifamily foreclosures on single-family house prices as a means for disentangling the causal mechanisms of foreclosure spillovers. He does not examine the effect of foreclosures on multifamily or condo prices. In effect, his study takes the opposite approach to that of Campbell, Giglio, and Pathak (2011). In this paper, we control for the structure type of both the foreclosed properties and the property sold at arm's-length, the price of which is on the left-hand side and is our focus.
} 
example, on the price of nearby condominiums. ${ }^{7}$

\section{Data}

The principal source of data for the analysis in this paper is a dataset of public records and assessor's files compiled for properties in Boston by the Warren Group, a local firm. The public records data contain, in principle, all sale and mortgage deeds recorded since 1987 for every residential property, and the assessor's files contain a contemporary snapshot of the characteristics of all properties. Researchers have used the Warren Group dataset extensively in the past, most notably to study foreclosure externalities in Campbell, Giglio, and Pathak (2011), although Foote, Gerardi, and Willen (2008) and Fisher and Lambie-Hanson (2012) use it to estimate foreclosure and sale hazards. For the bulk of our analysis, we follow the procedures used by Campbell, Giglio, and Pathak (2011) to clean the data. ${ }^{8}$ In total, the dataset includes approximately 2 million sales of single-family, small multifamily (2-3 units), and condo properties in Massachusetts between January 1987 and June 2012, with about 215,000 of these occurring in Boston.

Although the Warren Group data include transactions from 1987 to the present, we limit our sample to condo properties that transacted between the first quarter of 1989 and the second quarter of 2011 in order to accommodate our foreclosure window, which, as explained in Section 1, extends one year prior to the foreclosure sale and two years after. Our definition of repeat sales includes only what we consider true arm's-length sales. Foreclosure auctions are excluded, as well as sales of REOs. ${ }^{9}$ In addition, we attempt to exclude short sales, transactions in which the lender allows the borrower to sell for less than the amount owed on the mortgage rather than complete a foreclosure. We exclude likely short sales by removing transactions in which the sale price is

\footnotetext{
${ }^{7}$ For details on this result, see Table A.19 of Campbell, Giglio, and Pathak's online appendix, available at http://www . aeaweb.org/aer/data/aug2011/20090375_app.pdf.

${ }^{8}$ See http://www . aeaweb.org/aer/data/aug2011/20090375_app.pdf.

${ }^{9}$ When a foreclosure occurs between two arm's-length sales, we control for this using a dummy in our regression models.
} 
less than 75 percent of the combined origination amounts of mortgages taken out when the owner purchased the property. ${ }^{10}$ We also exclude intrafamily transactions, sales in which the seller held the property for fewer than 7 days and sales with prices below $\$ 10,000$ or over $\$ 10$ million.

We successfully geocoded 96 percent of the property locations using the ArcGIS 10 North American geocoding tool, achieving rooftop-level precision for a large proportion of our sample. After geocoding, we measured the distance between each property and its neighbors within 0.1 mile, using the Vincenty ellipsoidal distance formula. Figure 1 displays the scale of the 0.1mile buffers, which typically amounts to a couple of city blocks in Boston. ${ }^{11}$

As shown in Figure 2, foreclosures of condos have occurred in virtually every neighborhood of Boston, often in neighborhoods with a mix of singlefamily, multifamily, and condo properties. Citywide, about 3,400 foreclosures of single-family, 2-3 family, and condo properties were completed between 2007 and 2011. About 42 percent of these were foreclosures on condos. In the previous wave of foreclosures in Massachusetts in 1991-1994, approximately 5,400 foreclosures were completed, 52 percent of which involved condos. Condo associations in Boston come in all sizes, ranging from a single converted duplex to a set of large multifamily buildings, comprising hundreds of units.

For the most part, researchers measuring foreclosure externalities have looked at similarly limited geographic areas. Immergluck and Smith (2006) examine data from Chicago; Schuetz, Been, and Ellen (2008) have data from New York City; and Campbell, Giglio, and Pathak (2011) use the same dataset we do, which covers Massachusetts. Harding, Rosenblatt, and Yao (2009) and Gerardi et al. (2012) use datasets with fairly broad national coverage. The disadvantage of our sample is that the results might not generalize to other locations, but the advantage is that we can explicitly identify units located in

\footnotetext{
${ }^{10}$ For more information on identifying likely short sales using this rule and for a comparison of the recent volume of foreclosures and short sales in a community adjacent to Boston, see Fisher, Lambie-Hanson, and Willen (2011). When we include short sales, we find somewhat stronger evidence that same-association foreclosures drive estimates of foreclosure spillovers.

${ }^{11}$ We estimate our main regression models using neighbors within 0.1 mile, but as a robustness check, we also report results using neighbors 0.25 mile away.
} 
the same condo associations (and further, within the same or different buildings), which is something that no one has been able to do yet with a national dataset.

\section{$2.1 \quad$ Identifying condo associations}

In Boston, units in the same condo association share the same first seven digits of the assessor's parcel number, making it possible to identify a unit's association in over 95 percent of our condo sample. Overall, our final sample contains 34,094 arm's-length repeat-sales condominium pairs, almost exactly half of which are part of small associations with fewer than 13 units. Table 2 shows that there was a foreclosure within 0.1 mile of 41 percent of these transactions, with 37 percent located near a foreclosure of another condo unit. Foreclosures in the same association are not uncommon, particularly among large associations. About 21 percent of sellers in the largest associations shared an association with a property in foreclosure, while only about 2 percent of sellers in small associations (12 or fewer units) had foreclosures in their association.

Our data allow us to decompose the same-association foreclosures further into those that occurred on units that were located at the same street address and those that were located at different addresses. Not surprisingly, most of the same-association foreclosures in small associations are located at the same street address. The small number of observations in 4 to 12-unit associations with foreclosures in the same association but at a different address (SADA) are typically less than 40 feet away $(.007$ miles $)$ from the foreclosures. In contrast, SADA foreclosures in associations with more than 12 units are, on average, over twice as far away. In the analysis that follows, we treat all sameassociation foreclosures in associations with 12 or fewer units equally and do not distinguish between same and different addresses. While this is in part due to the lack SADA foreclosures, for all practical purposes, the instances of SADA foreclosures in small associations are very nearby.

Finally, we draw the reader's attention to the last row in Table 2, which 
shows that condo foreclosures in neighboring, different associations are located about equally far away from their neighbors, on average, among associations of different sizes.

We know of no other assessors in the state who follow Boston's convention of linking parcel numbers and associations, making it impossible for us to identify associations anywhere except in Boston. As Table 2 illustrates, defining associations by address would lead to a substantial understatement of the extent of same-association foreclosures, particularly in large associations. In Boston, there were about half as many condominiums with foreclosures in the same association but a different address as condos with foreclosures at the same address.

\subsection{Sample Characteristics by Association Size}

Table 3 presents summary statistics for our sample of repeat sales of condominiums in Boston. We continue to stratify the sample in order to describe how condos vary by association size. Differences in median price and unit characteristics across groups in the first panel of Table 3 are unremarkable, with the possible exception of neighborhood density. The differing density across association type could confound our results if the number of foreclosures relative to the size of the housing stock is the source of the externality. As a robustness check, we control for density in our main regression model and the results, reported below, are unaffected. While buildings in large associations tend be newer, relatively few condo buildings have been built since 1990 .

While our repeat-sales transactions are all condominiums, we measure and differentiate all nearby foreclosures by structure type: single-family, multifamily, and condominium. Small multifamily properties, which are common in Boston, are comprised of 2 to 3-unit rental buildings. Among transactions in associations of different sizes, there is little difference in the average number or composition of nearby foreclosures. Unsurprisingly, condos in larger associations have more foreclosures in the same association. We also estimate that our sample of transactions is only comprised of a small fraction of townhouse 
structures, defined as associations with greater than 50 percent of units having unique addresses.

\section{Results}

As introduced above, we regress each property's growth in price on a series of census tract $\times$ calendar year controls and on the change in the number of nearby foreclosures. Table 4 displays our main results. Nearby foreclosures are initially stratified only by property type (single-family, multifamily, and condominium). In subsequent specifications, we differentiate condominium foreclosures according to whether or not foreclosures are in the same association as the subject property, and then by whether same association foreclosures are within the same building as the subject transactions.

In Column 1 of Table 4, we show that the negative effect of condo foreclosures on the prices of nearby condo properties is statistically significant but economically small at only 0.4 percent. Column 2 shows that same-association foreclosures have a larger impact on sale prices than do nearby condo foreclosures in other associations, and Column 3 indicates that these same-association foreclosures are more detrimental the smaller the association, and the effect is both statistically significant and economically meaningful in associations of 50 or fewer units. A same-association foreclosure lowers price by 8 percent in 2 to 3 -unit associations, 6 percent in 4 to 12 -unit associations, and 3 percent in associations of 13 to 50 units. ${ }^{12}$ Condo foreclosures in different associations have a statistically significant and negative impact on prices, but this effect is economically trivial when compared to the same-association effects.

We attempt to disentangle the mechanisms whereby foreclosures in the same association influence condo prices in Columns 4 and 5 of Table 4 . The results in Column 4 indicate that foreclosures in the same association and at the same address impose a discount of 2.5 percent, while same-association, different-address foreclosures appear to have no effect. However, it is hard in this specification to tease out the impact of distance from that of association

\footnotetext{
${ }^{12}$ The percentage change in sales price is captured by $100\left(e^{\gamma}-1\right)$.
} 
size, since we know from Column 3 that small associations experience the largest foreclosure spillover effects and from Table 2 that same-association foreclosures are located nearer, on average, in small associations.

Our main specification, found in Column 5, differentiates foreclosures at the same versus different addresses within large associations and reveals that the negative externality of a foreclosure, at least among larger associations, is truly a product of proximity. In larger associations, having a foreclosure very nearwithin the same building - imparts a negative impact on prices of between 1.5 and 3 percent, depending on the association size. ${ }^{13}$ While we cannot rule out a fiscal effect resulting from foreclosures within small associations, we are confident that among large associations, physical proximity to a foreclosure is more important than its effect on the overall association. Foreclosures within the same association but at different addresses produce impacts that are not significantly different from zero. Likewise, condo foreclosures in neighboring but different associations produce negligible impacts on prices.

\subsection{Robustness}

In specifying these models, we acknowledged a number of challenges. Tables 5 and 6 display a number of robustness check on our main result, found in Column 5 of Table 4 . The first column of Table 5 repeats our main specification. In Column 2, we control for neighborhood density (log number of neighboring properties located within 0.1 mile of repeat-sales transactions) and other property characteristics that might influence price appreciation (specifically, the number of bedrooms and baths, square feet of living space, lot size, and age of the building). Our main results are unchanged, and none of the added controls are significantly different from zero (the latter are not reported in the table).

In Column 3, we remove the dummy controlling for a foreclosure between

\footnotetext{
${ }^{13}$ In Table A-1 of the appendix we show that the results for the largest associations are identical when we restrict the sample to these associations, and when we restrict the sample to medium-sized associations, the results remain large (a foreclosure spillover effect of over 2 percent).
} 
the two arm's-length sales in the repeat-sales pair. Doing so substantially increases the coefficient on foreclosures in 2 to 3 -unit associations, but the rest of the results are relatively unchanged. As shown in Table 3, however, foreclosures were not much more prevalent in our sample of small-association units than in large-association units.

Next, we examine the sensitivity of our results to the inclusion of census tract $\times$ calendar year controls. In Column 4 of Table 5, we show that omitting the interaction of census tracts with calendar years (while retaining the main year dummies) increases virtually all of the estimated effects of foreclosures, in some cases more than doubling the coefficients. These results strongly argue for the inclusion of geographic controls. Reinstating census tract $\times$ year controls and recognizing that sample sizes may be small within some census tract/year combinations, in Column 5 we limit the sample to those properties for which at least 10 condo properties are observed to be purchased or sold in the tract in the same year. In other words, we arbitrarily limit the sample to have a minimum number of transactions by which to calculate a tract-level annual price change. Imposing this restriction reduces our sample size by over 6,100 transactions, with the greatest reduction in sample size for condo sales pairs selling a second time near the end of the sample period in 2011. This restriction leaves our main results virtually unchanged with the exception of 2 to 3-unit associations and 13 to 50-unit associations. We can in part attribute the smaller, less significant coefficients to the fact that about one-quarter of the observations in the 2 to 3 and 13 to 50-unit associations are dropped when the sample is restricted, as compared with just 13 percent and 15 percent of 4 to 12 -unit and 51+ unit associations. Further, as noted, the observations dropped come at the end of the sample (2008-2011), when foreclosures were more common.

Finally, Columns 6 and 7 of Table 5 demonstrate that our results are very similar when we restrict the sample to observations with two or more sales in their block group in the particular sale year and substitute block groups in lieu of tracts for the neighborhood-year controls.

In Column 2 of Table 6 we expand the distance defining "nearby" foreclosures 
from 0.1 mile to 0.25 mile. Consistent with our previous results that condo foreclosures' impacts are contained within condo associations, this expansion generates virtually no changes to our main result. In the next two columns, we restrict the time window before and after foreclosures during which we count foreclosures as active. In our main specification, we count foreclosures as active for the year prior to, and for the two years following, the foreclosure deed. In Column 3 of Table 6 , we maintain the window of one year before a foreclosure, but reduce the period following it to only one year. The precision of some of our estimates fall due a reduction in the number of foreclosures for which we account, but generally, the magnitude and significance of the coefficients remain unchanged. The main impact of changing how we count foreclosures is the impact of same-association but different-address foreclosures in associations with 13 to 50 units, which approaches the size of the corresponding SASA effect and is statistically significant. In Column 4 we restrict our definition of active foreclosures to encompass only 6 months before and after a foreclosure, and we note that in both Columns 3 and 4 the coefficients are not very stable due to reductions in power, especially for the smallest associations. As the time window becomes narrower, the coefficients tend to become somewhat greater in magnitude, signalling that the effects of neighboring foreclosure gradually attenuate over time. However, we draw the reader's attention to the SADA coefficient for associations of 51 or more units, which is effectively zero across these specifications.

As a final robustness check, we expand our sample to include all possible transactions by specifying a hedonic model similar to equation (1) with the addition of census tract $\times$ year controls. Active foreclosures are defined as they are in our main specification, based on a window of 1 year before and 2 years following a foreclosure auction. The first difference between the hedonic results and our main repeat sales result is that in the hedonic model nearby single-family foreclosures lower condo prices by a marginally significant 1.5 percent. Given that neither the repeat sales nor the hedonic model identifies economically meaningful impacts of condo foreclosures in different associations on nearby condo prices, nor any multifamily foreclosure impacts, it is 
somewhat difficult to reconcile why nearby single-family foreclosures should influence condo prices. We conjecture that the finding is a result of omitted variables, whereby the hedonic specification fails to sufficiently capture characteristics of condo buildings that abut single-family neighborhoods.

\section{Discussion}

In the introduction, we motivated the paper by arguing that we could use our data to test different hypotheses about the nature of the discount that foreclosures impose on sale prices of nearby properties. Our analysis yields yields three stylized facts. First, same-address foreclosures have a much stronger effect on prices than different-address foreclosures even when constrain our attention to properties in the same association. Second, when we focus on the large associations that account for almost two-thirds of same-association foreclosures, we find that different-address (SADA) foreclosures have no effect on the price of condominiums, whereas same-address (SASA) foreclosures have an economically and statistically significant effect. Third, for smaller associations, the picture is more nuanced with SADA foreclosures having an economically but not statistically significant effect. How do we make sense of these findings. Our view is that there is strong evidence of a physical externality of foreclosed properties. There is also evidence of a public good externality, and we think there is little evidence of a pecuniary externality.

In a sense, nearby properties should be the closest substitutes for a property that sells. But choosing a radius of 0.1 mile is somewhat arbitrary, and it means we must believe that properties within 0.1 mile are closer substitutes than, say, properties between 0.1 mile and 0.25 mile. In contrast, it may be reasonable to view a property in an association as a closer substitute than a property in another association, even if the different-association property is geographically closer. Condominiums in the same association typically share similar characteristics - floor plans, finishes, appliances - that are unobservable to the econometrician and raise questions about identification in house price modeling. Thus, if the same-association effect documented in Table 4 
reflected the fact that same-association units were close substitutes, we would expect the effect to be comparable when same-association properties are located at different addresses. But the data show that this is not the case in large associations, where same-association foreclosures can commonly be found at either the same or different addresses (Column 5, Table 4). Same-association, different-address foreclosures have substantially smaller impacts on neighboring condo prices than do same-address foreclosures. This study investigates only neighboring foreclosures located within 0.1 and 0.25 mile, so we cannot directly speak to the impact of a foreclosure on the sale price of a property located farther away. However, given that foreclosures have negligible impacts on properties outside their associations but located nearby, we think it is unlikely that they would have substantial impacts on properties located farther away.

In the remainder of this section, we first discuss the character of the physical externality. Second, we argue that a feature of Massachusetts law can explain the pattern of effects across association sizes and suggests that the public good externality is important for smaller associations.

\subsection{Physical Externalities in Condo Associations}

The nature of condominium ownership can both aggravate and mitigate the physical externality problem resulting from a delinquent homeownership. The communal ownership structure can limit the effect on maintenance and upkeep of an individual delinquent homeowner. The owner of a single-family property facing foreclosure may stop doing routine maintenance like landscaping or, in a more extreme situation, abandon the property to squatters. But in a condominium, a solvent association will make sure that landscaping is done, that trash is collected and that the property is secure from squatters. On the other hand, the fact that condo owners live in such close proximity to one another means that poor maintenance is much more likely to affect neighbors. For example, if the owner of a single-family unit turns off the heat, neighbors will not notice, but in a condo building, they will typically face increased 
heating costs.

While there is ample anecdotal evidence of the effects of the physical externalities of foreclosures in condo associations, we attempted to get some more systematic evidence from constituent complaints about property conditions to local government. ${ }^{14}$ We inspected the same constituent complaints data used by Lambie-Hanson (2013) to learn about the types of complaints that arise about condos in foreclosure. Examining a sample of 456 condo units with a foreclosure start between June 2008 and December 2011, we found that 186 of the properties (41 percent) experienced at least one complaint about the conditions of their buildings while the owners were in foreclosure or while the properties were bank owned, with these properties logging a total of 400 complaints. While some of the complaints reflected neighborhood-level disamenities like failure to clear snow after a storm or improper storage of trash, many complaints related to the interior conditions of the properties. A number of the issues raised stemmed from failure of the condo association to keep the buildings in proper working order, including turning on heat in the winter or fixing leaky roofs, which may signal problems with association financial solvency. Further, some complaints referenced problems that arise when owners or occupants of other units are negligent, including dumping of trash in common areas, ceilings collapsing due to plumbing failures in upstairs units, and pest infestations. In fact, 47 complaints in the sample we examined (well over 10 percent of all property condition complaints), filed in 32 unique buildings, specifically referenced mice, rats, roaches, and other pests as a problem inside the property. According to the verbatim records of the complaints, often the constituents argued that the pests were originating from other units in the building. To the extent that a foreclosure leads to worse care of a condo unit and that these problems may spill over into other units in the same building, it may be particularly detrimental to share a building with a foreclosed property, enough so that one's sale price could be negatively impacted.

\footnotetext{
${ }^{14}$ For anecdotal evidence, see "Failed Condos Take Toll on Fenway; Drug Dealers, Prostitutes Filling Vacant Units," Boston Globe, December 6, 1992.
} 


\subsection{Fees, Public Goods, and the Superlien Law}

For smaller associations, as discussed already, we find that the effect of sameassociation foreclosures is much larger, and we find that SADA foreclosures have an economically meaningful although statistically insignificant effect. We view this is as evidence that a public good externality exists. When individual borrowers stop paying their association fees, the remaining owners must either pay more or accept reduced amenities, and the effects can sometimes be catastrophic and render an entire association uninhabitable. ${ }^{15}$ It is important to stress that the public good externality and the physical externality are both economically and observationally distinct. The physical externality results from poor maintenance of an individual unit and affects only properties that are physically close, whereas the public good externality results from the failure of the individual owner to contribute to common expenses and affects the entire association, regardless of location within the association.

Our confidence about the existence of this public good problem comes, paradoxically, from its absence in large associations. The key here is that during the housing downturn of the late 1980s, non-payment of association fees became a statewide crisis. ${ }^{16}$ The result was that in 1992, Massachusetts passed a so-called super-lien law. ${ }^{17}$ Massachusetts General Laws Chapter 183A, Section 6 creates a priority lien for condo associations over a first mortgage for up to six months of delinquent common expense assessments (or more colloquially, condo fees). In practice, the priority lien limit of six months of common expenses has been circumvented by the use of "rolling" liens, whereby associations file suit every six months that an owner remains delinquent in order

\footnotetext{
${ }^{15}$ For examples in Massachusetts, see "Delinquencies of Condo and Co-op Owners Rising," The New York Times, February 3, 1991 and "Condos Face Fragile Future; Fiscal, Physical End Of Hub Site Points To Larger Problem Demise Of Hub Condo Points To Common Crisis" Boston Herald, December 31, 1991.

${ }^{16}$ The condominium ownership structure only emerged in the U.S. in the 1960s and was not widely adopted in Massachusetts until the 1970s (Lasner 2012). The house price decline in the late 1980s represented the first time of widespread negative equity among condo owners in Massachusetts.

${ }^{17}$ Sample size issues prevent us from exploiting the change in the law to measure the public goods problem.
} 
to secure a priority position for each additional six months' worth of common expenses. ${ }^{18}$ Reasonable attorney fees and other costs of collection may be recouped as part of the process to extinguish a priority lien. Late fees, penalties, and interest on delinquent fees are not eligible costs. ${ }^{19}$

Among large condo associations, attorneys claim that they rarely have to undertake action to enforce priority liens beyond providing notice of delinquency to first mortgagees. It is common for lenders to step in, bring fees current, and then continue to pay association fees during a period of mortgage delinquency prior to foreclosure. Doing so allows a first mortgage lender to extinguish an association's priority lien and preserve the priority of its mortgage. This process also allows expensive lawsuits to be avoided, while providing that associations may re-institute an action to enforce a priority lien if lenders fail to maintain their promises.

Industry experts report that smaller associations without formal management practices, professional management or established legal representation are less likely or less timely in taking advantage of the super-lien law. Failure to follow the statute's procedures or timelines can reduce the amount of money that associations can recover. By definition in the statute, a priority lien exists only to the extent that assessments for common expenses are made at least annually based on an annually-adopted budget. Very small associations, in particular, may not have a formal budget or regular assessments. Overall, we are confident that since 1993 large condo associations in Massachusetts have suffered few adverse effects from condo fee delinquency. Outcomes for smaller associations are more likely to vary.

Another possibility is that having information about co-owners may be of greater importance for prospective buyers in small associations. Barzel and Sass (1990) point out that a prospective buyer's valuation will depend not

\footnotetext{
${ }^{18}$ Subsequent to our sample period, a 2011 decision based on the appeal of a court case challenging rolling liens has affirmed a lower court ruling that no more than six months of common expenses may gain a priority status (see Drummer Boy Homes Association, Inc. v. Britton, 2011 Mass. App. Div. 186).

${ }^{19}$ These costs are part of the personal liability of the delinquent owner, however, and may comprise a lien that does not receive priority over the first mortgage.
} 
only on the current value of a condo, but also on her expectations about future maintenance of the building and the costliness of participating in its governance. Coulson and Fisher (2014) show that free-riding issues are more severe in small homeowner associations where more maintenance and management is self-performed. Therefore, the characteristics of neighbors in small associations may matter more to a prospective buyer than in a large association. In addition, decision-making within small associations may operate on the basis of owner consensus, and the prospect of a stalemate or personal tension among owners may make it desirable to screen neighbors for compatibility. $^{20}$ If buyer screening of other owners is important in small associations, then delinquency and foreclosure - which generate uncertainty about future co-owners - may increase buyer discounts due to the concomitant uncertainty about future maintenance decisions and decision-making costs. This effect may serve to exacerbate the current maintenance externality that we identify. These same concerns are far less likely to be important in large associations, where professional management and more neighbors insulate the association from the turnover of only a few owners.

\section{Conclusions}

Early in the foreclosure crisis, some argued that government policy had little role to play because foreclosures represented the disposition of private contracts. But as foreclosures mounted, policymakers began to worry about foreclosure externalities and to formulate strategies to protect those who were not party to the failed mortgage contracts but were suffering nonetheless. To justify intervention, policymakers appealed to research that showed that foreclosures depressed the prices of neighboring properties. However, as we discussed in the introduction, that research alone was not sufficient: if discounts on neighboring properties represented a pecuniary externality, policies

\footnotetext{
${ }^{20}$ Hansmann (1991) argues that this is one virtue of the cooperative style of multifamily ownership as compared with condos; existing coop owners are able to screen prospective buyers.
} 
to prevent foreclosures could simply transfer surplus from one member of society to another but not to increase it.

Our main findings are that the foreclosures in the same large condo association but at a different address have no effect on prices, whereas foreclosures at the same address have a strong effect. If pecuniary externalities were a major issue, then these same-association, different-address foreclosures should have a large effect on prices, as they are close substitutes. Thus, our analysis of condominium foreclosures in Boston shows that the discounts generated by nearby foreclosures are a physical externality, which can clearly justify active policies aimed at preventing or mitigating foreclosures. 
Figure 1: ApPlying 1/10Th AND 1/4-Mile BUfFERS AROUND ARM'SLENGTH SALES.



Source: Authors' analysis of Warren Group data.

Note: This example shows 1/10th-mile and 1/4-mile buffers drawn around an arm's-length sale (star). Nearby foreclosures, streets, census tract boundaries, and building footprints are also displayed. 
Figure 2: LocAtions of FORECLOSURES IN Boston.
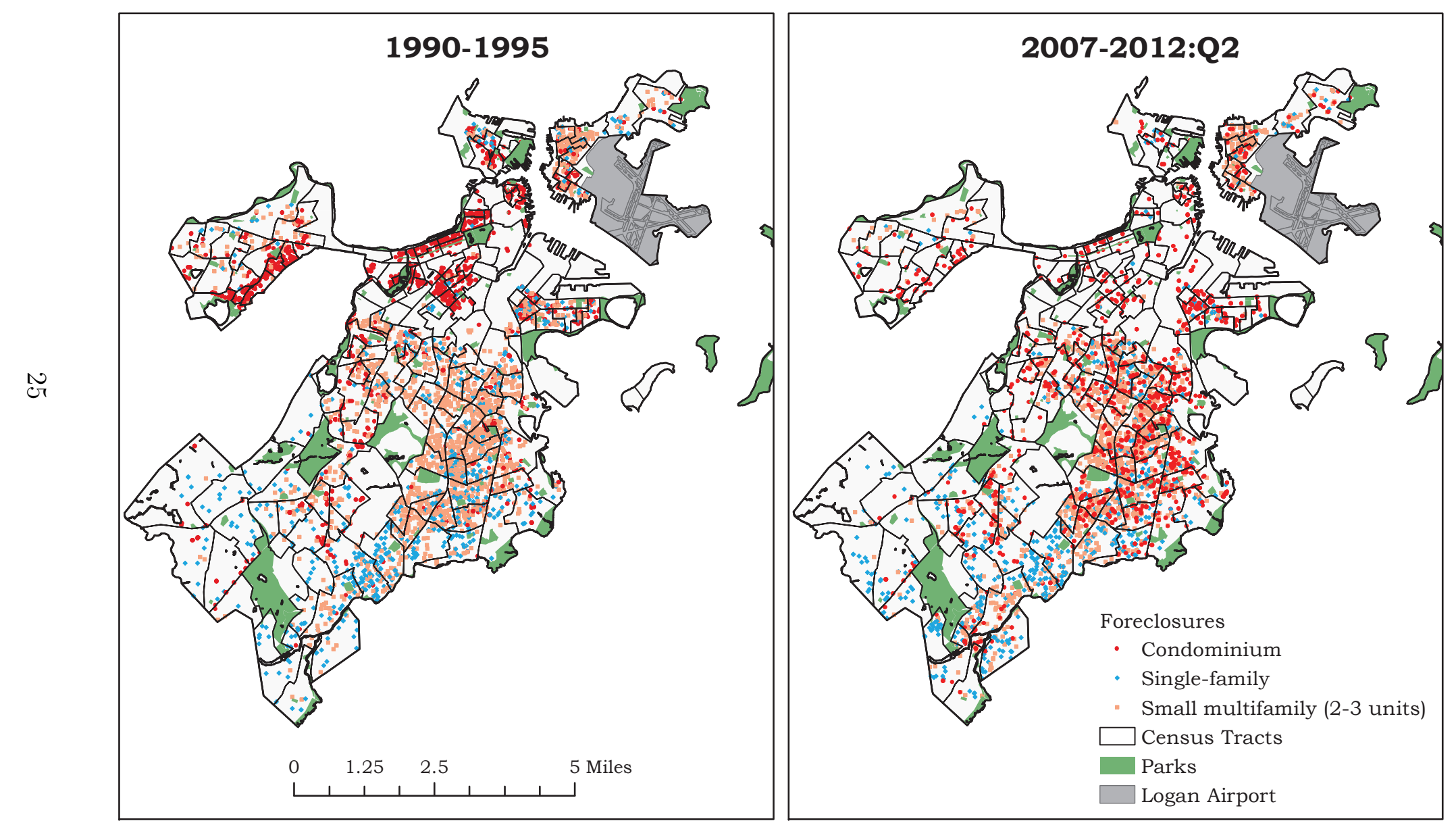

Source: Authors' analysis of Warren Group data.

Note: Figure shows foreclosure deeds filed between January 2007 and June 2012 on single-family, two-family, three-family, and condominium properties in the city of Boston. Census tract boundaries are displayed as grey lines. 
Table 1: Summary of findings.

\begin{tabular}{|c|c|c|c|c|c|c|}
\hline & \multicolumn{2}{|c|}{ Same Association } & \multicolumn{3}{|c|}{$S A S A-S A D A$} & \multirow{2}{*}{$\begin{array}{c}\text { Different Association } \\
\text { Different Address } \\
(D A D A)\end{array}$} \\
\hline & $\begin{array}{l}\text { Same Address } \\
(S A S A)\end{array}$ & $\begin{array}{c}\text { Different Address } \\
(S A D A)\end{array}$ & $\begin{array}{c}\text { Point } \\
\text { Estimate }\end{array}$ & $F$ & $p$-value & \\
\hline \multicolumn{7}{|c|}{ A. Full Sample. } \\
\hline & $\begin{array}{c}-0.025^{* *} \\
(0.004)\end{array}$ & $\begin{array}{l}-0.002 \\
(0.003)\end{array}$ & -0.023 & 22.06 & $<0.0001$ & $\begin{array}{c}-0.003^{* *} \\
(0.001)\end{array}$ \\
\hline \multicolumn{7}{|c|}{ B. Divided up by association size, in units. } \\
\hline 2 to 3 & $\begin{array}{c}-0.087^{* *} \\
(0.028)\end{array}$ & - & - & - & - & \multirow{4}{*}{$\begin{array}{c}-0.003^{* *} \\
(0.001)\end{array}$} \\
\hline 4 to 12 & $\begin{array}{c}-0.062^{* *} \\
(0.013)\end{array}$ & - & $\overline{-}$ & $\overline{-}$ & - & \\
\hline 13 to 50 & $\begin{array}{c}-0.032^{* *} \\
(0.008) \\
\end{array}$ & $\begin{array}{l}-0.014 \\
(0.013) \\
\end{array}$ & -0.018 & 1.01 & 0.3156 & \\
\hline $51+$ & $\begin{array}{c}-0.015^{* * *} \\
(0.004)\end{array}$ & $\begin{array}{l}-0.002 \\
(0.003)\end{array}$ & -0.013 & 8.61 & 0.0039 & \\
\hline
\end{tabular}


Table 2: Foreclosures neAR COndominiums sold in Boston, 1987-2011.

\begin{tabular}{|c|c|c|c|c|c|c|c|c|c|}
\hline & \multicolumn{4}{|c|}{$\begin{array}{l}\text { Number of Repeat Sales } \\
\text { by association size (units) }\end{array}$} & \multicolumn{5}{|c|}{$\begin{array}{c}\text { Percent of Total } \\
\text { by association size (units) }\end{array}$} \\
\hline & 2 to 3 units & $4-12$ & $13-50$ & $51+$ & 2 to 3 & $4-12$ & $13-50$ & $51+$ & All \\
\hline All Condos & 5,731 & 11,362 & 8,285 & 8,716 & 100 & 100 & 100 & 100 & 100 \\
\hline $\begin{array}{l}\text { Condos with }>0 \\
\text { foreclosures within } 0.1 \text { mile }\end{array}$ & 2,384 & 4,824 & 3,197 & 3,446 & 42 & 42 & 39 & 40 & 41 \\
\hline $\begin{array}{l}\text { Condos with }>0 \text { condo } \\
\text { foreclosures within } 0.1 \text { mile }\end{array}$ & 1,930 & 4,414 & 2,989 & 3,389 & 34 & 39 & 36 & 39 & 37 \\
\hline ...within same association & 92 & 263 & 689 & 1,849 & 2 & 2 & 8 & 21 & 8 \\
\hline ......and at same address & 92 & 219 & 541 & 1,205 & 2 & 2 & 7 & 14 & 6 \\
\hline .......and at different address & 0 & 48 & 179 & 794 & 0 & 0 & 2 & 9 & 3 \\
\hline mean distance (miles) & n.a. & 0.007 & 0.015 & 0.031 & & & & & \\
\hline ...in different association & 1,906 & 4,322 & 2,655 & 2,324 & 33 & 38 & 32 & 27 & 33 \\
\hline mean distance (miles) & 0.064 & 0.061 & 0.062 & 0.065 & & & & & \\
\hline
\end{tabular}

Source: Authors' calculations of Warren Group and City of Boston Assessing Department data. Note that the sum of same-association, same-address foreclosures and same-association, different-address foreclosures exceeds the number of same association foreclosures because some repeat sales have both within $\leq 0.1$ mile. Only the second sale in each repeat-sales pair is included. 
Table 3: Summary statistics For Boston Repeat sales Sample, 1989:Q1 то 2011:Q2.

\begin{tabular}{|c|c|c|c|c|}
\hline & \multicolumn{4}{|c|}{ Condos, by association size (units) } \\
\hline & 2 to 3 & 4 to 12 & 13 to 50 & $51+$ \\
\hline Number of repeat-sales pairs & 5,731 & 11,362 & 8,285 & 8,716 \\
\hline \multicolumn{5}{|l|}{ Median } \\
\hline Price (second sale) & $\$ 420,718$ & $\$ 449,405$ & $\$ 342,591$ & $\$ 422,934$ \\
\hline Price (initial sale) & $\$ 333,071$ & $\$ 324,612$ & $\$ 246,211$ & $\$ 306,470$ \\
\hline Properties $\leq 0.1$ mile away & 406 & 583 & 425 & 438 \\
\hline Full baths & 1 & 1 & 1 & 1 \\
\hline Half baths & 0 & 0 & 0 & 0 \\
\hline Living area in sq. $\mathrm{ft}$. & 1,139 & 983 & 903 & 959 \\
\hline \multicolumn{5}{|l|}{ Year Built (Percent) } \\
\hline pre 1900 & 46 & 55 & 29 & 12 \\
\hline $1900-1939$ & 46 & 36 & 44 & 27 \\
\hline $1940-1970$ & 1 & 2 & 11 & 23 \\
\hline $1971-1990$ & 2 & 4 & 12 & 30 \\
\hline post 1990 & 5 & 3 & 5 & 8 \\
\hline \multicolumn{5}{|c|}{ Mean Number of foreclosures $\leq 0.1$ mile away, conditional on $>0$} \\
\hline All structure types & 6 & 6 & 6 & 6 \\
\hline Single-family & 1 & 1 & 1 & 1 \\
\hline Multifamily & 2 & 2 & 1 & 2 \\
\hline Condo & 3 & 3 & 3 & 3 \\
\hline Same-association & 1 & 1 & 2 & 2 \\
\hline Neighboring-association & 3 & 3 & 3 & 3 \\
\hline \multicolumn{5}{|l|}{ Other characteristics } \\
\hline Median condo units in association & 3 & 6 & 27 & 108 \\
\hline Townhouses (percent) & 3 & 4 & 5 & 2 \\
\hline Foreclosure between arm's-length sales (percent) & 2 & 1 & 2 & 1 \\
\hline
\end{tabular}

Sources: Authors' calculations of Warren Group and City of Boston Assessing Department data. 
Table 4: Results from Boston Repeat-Sales analysis: Condo ReSULTS BY ASSOCIATION SIZE AND TYPE OF NEIGHBORING FORECLOSURES.

\begin{tabular}{|c|c|c|c|c|c|}
\hline & 1 & 2 & 3 & 4 & 5 (Main) \\
\hline \multicolumn{6}{|c|}{ Change in number of foreclosures within 0.1 mile... } \\
\hline Single-family & $\begin{array}{c}0.003 \\
(0.005)\end{array}$ & $\begin{array}{c}0.003 \\
(0.005)\end{array}$ & $\begin{array}{c}0.003 \\
(0.005)\end{array}$ & $\begin{array}{c}0.004 \\
(0.005)\end{array}$ & $\begin{array}{c}0.004 \\
(0.005)\end{array}$ \\
\hline Multifamily & $\begin{array}{c}0.004 \\
(0.008)\end{array}$ & $\begin{array}{c}0.004 \\
(0.008)\end{array}$ & $\begin{array}{c}0.004 \\
(0.007)\end{array}$ & $\begin{array}{c}0.005 \\
(0.008)\end{array}$ & $\begin{array}{c}0.005 \\
(0.007)\end{array}$ \\
\hline Condo & $\begin{array}{c}-0.004^{* * *} \\
(0.001)\end{array}$ & & & & \\
\hline Different association & & $\begin{array}{c}-0.003^{* * *} \\
(0.001)\end{array}$ & $\begin{array}{c}-0.003^{* * *} \\
(0.001)\end{array}$ & $\begin{array}{c}-0.003^{* * *} \\
(0.001)\end{array}$ & $\begin{array}{c}-0.003^{* * *} \\
(0.001)\end{array}$ \\
\hline Same association & & $\begin{array}{c}-0.008^{* *} \\
(0.004)\end{array}$ & & & \\
\hline SA 2 to 3 & & & $\begin{array}{c}-0.086^{* * *} \\
(0.028)\end{array}$ & & $\begin{array}{c}-0.087^{* * *} \\
(0.028)\end{array}$ \\
\hline SA 4 to 12 & & & $\begin{array}{c}-0.062^{* * *} \\
(0.013)\end{array}$ & & $\begin{array}{c}-0.062^{* * *} \\
(0.013)\end{array}$ \\
\hline SA 13 to 50 & & & $\begin{array}{c}-0.026^{* * *} \\
(0.006)\end{array}$ & & \\
\hline $\mathrm{SA} 51+$ & & & $\begin{array}{l}-0.005 \\
(0.003)\end{array}$ & & \\
\hline SASA & & & & $\begin{array}{c}-0.025^{* * *} \\
(0.004)\end{array}$ & \\
\hline SADA & & & & $\begin{array}{c}-0.002 \\
(0.003)\end{array}$ & \\
\hline SASA 13 to 50 & & & & & $\begin{array}{c}-0.032^{* * *} \\
(0.008)\end{array}$ \\
\hline SADA 13 to 50 & & & & & $\begin{array}{l}-0.014 \\
(0.013)\end{array}$ \\
\hline SASA $51+$ & & & & & $\begin{array}{c}-0.015^{* * *} \\
(0.004)\end{array}$ \\
\hline SADA $51+$ & & & & & $\begin{array}{l}-0.002 \\
(0.003) \\
\end{array}$ \\
\hline \multicolumn{6}{|l|}{ Controls } \\
\hline Census tract-year & $\checkmark$ & $\checkmark$ & $\checkmark$ & $\checkmark$ & $\checkmark$ \\
\hline Experienced foreclosure dummy & $\checkmark$ & $\checkmark$ & $\checkmark$ & $\checkmark$ & $\checkmark$ \\
\hline Association size & $\checkmark$ & $\checkmark$ & $\checkmark$ & $\checkmark$ & $\checkmark$ \\
\hline Observations (repeat-sales pairs) & & & 34,094 & & \\
\hline R-squared & 0.736 & 0.736 & 0.738 & 0.737 & 0.738 \\
\hline
\end{tabular}

Source: Authors' calculations of Warren Group and City of Boston Assessing Department data. Note: ${ }^{* * *},{ }^{* *}$, and ${ }^{*}$ represent statistical significance at 1,5 , and 10 percent levels, respectively. Model 1 demonstrates that there is a small but statistically significant negative spillover from each additional nearby condo foreclosure. Model 2 breaks these foreclosures down by those in the same association versus those that are located nearby but in different associations, indicating that same-association foreclosures drive the price spillovers. Model 3 shows that these same-association foreclosures are most detrimental in smaller associations. Model 4 shows that same-association foreclosures are harmful when located at the same address. Model 5 further supports this, showing that, for large associations (where same-association, different-address foreclosures are most likely to be found), same-address foreclosures have stronger impacts on prices than different-address foreclosures in the same association. 
Table 5: Robustness: Alternative COntrols for neighborhood And Property CHARACTERISTiCs.

\begin{tabular}{|c|c|c|c|c|c|c|c|}
\hline & $\begin{array}{c}1 \\
\text { Main }\end{array}$ & $\begin{array}{c}2 \\
\text { Property } \\
\text { Controls }\end{array}$ & $\begin{array}{c}3 \\
\text { No Foreclosure } \\
\text { Control }\end{array}$ & $\begin{array}{c}4 \\
\text { No Tract } \\
\text { Controls }\end{array}$ & $\begin{array}{c}5 \\
\text { Restricted } \\
\text { Sample }(10+)\end{array}$ & $\begin{array}{c}6 \\
\text { BG } \\
\text { Sample }\end{array}$ & $\begin{array}{c}7 \\
\text { BG } \\
\text { Controls }\end{array}$ \\
\hline \multicolumn{8}{|c|}{ Change in number of foreclosures within 0.1 mile... } \\
\hline Single-family & $\begin{array}{c}0.004 \\
(0.005)\end{array}$ & $\begin{array}{c}0.003 \\
(0.005)\end{array}$ & $\begin{array}{c}0.003 \\
(0.005)\end{array}$ & $\begin{array}{l}-0.001 \\
(0.003)\end{array}$ & $\begin{array}{c}0.003 \\
(0.004)\end{array}$ & $\begin{array}{c}0.007 \\
(0.005)\end{array}$ & $\begin{array}{c}0.009 \\
(0.006)\end{array}$ \\
\hline Multifamily & $\begin{array}{c}0.005 \\
(0.007)\end{array}$ & $\begin{array}{c}0.005 \\
(0.007)\end{array}$ & $\begin{array}{c}0.004 \\
(0.008)\end{array}$ & $\begin{array}{c}-0.016^{* * *} \\
(0.002)\end{array}$ & $\begin{array}{c}0.008 \\
(0.010)\end{array}$ & $\begin{array}{c}0.012 \\
(0.009)\end{array}$ & $\begin{array}{c}0.011 \\
(0.010)\end{array}$ \\
\hline Different association & $\begin{array}{c}-0.003^{* * *} \\
(0.001)\end{array}$ & $\begin{array}{c}-0.003^{* * *} \\
(0.001)\end{array}$ & $\begin{array}{c}-0.003^{* * *} \\
(0.001)\end{array}$ & $\begin{array}{c}-0.005^{* * *} \\
(0.000)\end{array}$ & $\begin{array}{c}-0.003^{* * *} \\
(0.001)\end{array}$ & $\begin{array}{c}-0.002^{* *} \\
(0.001)\end{array}$ & $\begin{array}{c}-0.003^{* *} \\
(0.001)\end{array}$ \\
\hline SA 2 to 3 & $\begin{array}{c}-0.087^{* * *} \\
(0.028)\end{array}$ & $\begin{array}{c}-0.087^{* * *} \\
(0.028)\end{array}$ & $\begin{array}{c}-0.109^{* * *} \\
(0.030)\end{array}$ & $\begin{array}{c}-0.157^{* * *} \\
(0.018)\end{array}$ & $\begin{array}{c}-0.057^{* * *} \\
(0.021)\end{array}$ & $\begin{array}{c}-0.079^{* * *} \\
(0.025)\end{array}$ & $\begin{array}{c}-0.078^{* * *} \\
(0.029)\end{array}$ \\
\hline SA 4 to 12 & $\begin{array}{c}-0.062^{* * *} \\
(0.013)\end{array}$ & $\begin{array}{c}-0.062^{* * *} \\
(0.013)\end{array}$ & $\begin{array}{c}-0.066^{* * *} \\
(0.013)\end{array}$ & $\begin{array}{c}-0.079^{* * *} \\
(0.006)\end{array}$ & $\begin{array}{c}-0.061^{* * *} \\
(0.014)\end{array}$ & $\begin{array}{c}-0.057^{* * *} \\
(0.013)\end{array}$ & $\begin{array}{c}-0.051^{* * *} \\
(0.014)\end{array}$ \\
\hline SASA 13 to 50 & $\begin{array}{c}-0.032^{* * *} \\
(0.008)\end{array}$ & $\begin{array}{c}-0.031^{* * *} \\
(0.008)\end{array}$ & $\begin{array}{c}-0.031^{* * *} \\
(0.009)\end{array}$ & $\begin{array}{c}-0.046^{* * *} \\
(0.003)\end{array}$ & $\begin{array}{l}-0.020^{*} \\
(0.010)\end{array}$ & $\begin{array}{c}-0.031^{* * *} \\
(0.009)\end{array}$ & $\begin{array}{c}-0.031^{* * *} \\
(0.009)\end{array}$ \\
\hline SADA 13 to 50 & $\begin{array}{l}-0.014 \\
(0.013)\end{array}$ & $\begin{array}{l}-0.014 \\
(0.014)\end{array}$ & $\begin{array}{l}-0.014 \\
(0.014)\end{array}$ & $\begin{array}{c}-0.024^{* * *} \\
(0.004)\end{array}$ & $\begin{array}{l}-0.004 \\
(0.017)\end{array}$ & $\begin{array}{l}-0.015 \\
(0.014)\end{array}$ & $\begin{array}{l}-0.016 \\
(0.015)\end{array}$ \\
\hline SASA $51+$ & $\begin{array}{c}-0.015^{* * *} \\
(0.004)\end{array}$ & $\begin{array}{c}-0.015^{* * *} \\
(0.004)\end{array}$ & $\begin{array}{c}-0.015^{* * *} \\
(0.004)\end{array}$ & $\begin{array}{c}-0.021^{* * *} \\
(0.002)\end{array}$ & $\begin{array}{c}-0.014^{* * *} \\
(0.003)\end{array}$ & $\begin{array}{c}-0.016^{* * *} \\
(0.003)\end{array}$ & $\begin{array}{c}-0.018^{* * *} \\
(0.004)\end{array}$ \\
\hline SADA $51+$ & $\begin{array}{l}-0.002 \\
(0.003) \\
\end{array}$ & $\begin{array}{l}-0.002 \\
(0.003) \\
\end{array}$ & $\begin{array}{l}-0.002 \\
(0.003) \\
\end{array}$ & $\begin{array}{c}-0.005^{* * *} \\
(0.001)\end{array}$ & $\begin{array}{l}-0.003 \\
(0.003) \\
\end{array}$ & $\begin{array}{l}-0.002 \\
(0.003) \\
\end{array}$ & $\begin{array}{l}-0.003 \\
(0.005)\end{array}$ \\
\hline \multicolumn{8}{|l|}{ Controls } \\
\hline Census tract-year & $\checkmark$ & $\checkmark$ & $\checkmark$ & & $\checkmark$ & $\checkmark$ & \\
\hline $\begin{array}{l}\text { Block group-year } \\
\text { Year }\end{array}$ & & & & $\checkmark$ & & & $\checkmark$ \\
\hline Property characteristics & & $\checkmark$ & & & & & \\
\hline Experienced foreclosure dummy & $\checkmark$ & $\checkmark$ & & $\checkmark$ & $\checkmark$ & $\checkmark$ & $\checkmark$ \\
\hline Association size & $\checkmark$ & $\checkmark$ & $\checkmark$ & $\checkmark$ & $\checkmark$ & $\checkmark$ & $\checkmark$ \\
\hline Observations (repeat-sales pairs) & 34,094 & 34,094 & 34,094 & 34,094 & 27,948 & 32,619 & 32,619 \\
\hline R-squared & 0.738 & 0.739 & 0.737 & 0.657 & 0.713 & 0.737 & 0.768 \\
\hline
\end{tabular}

statistical significance at 1, 5, and 10 percent levels, respectively. Model 1 is our main model from Table 4. Model 2 adds neighborhood density and property controls (bedrooms, baths, square feet of living space, and property age). Model 3 shows the impact of removing the control for a foreclosure occurring between the two arm's-length sales in the repeat-sales pair. Model 4 shows the impact of removing census tract controls (though time controls are included). Model 5 restricts the sample to properties for which at least 10 condos are purchased/sold in the same year and tract that this property is purchased/sold. Models 6 and 7 restrict the sample to properties with at least 2 condos purchased/sold in the same year and block group, with Model 7 using block group-year controls instead of tract-year. 
Table 6: RoBustness: 0.25-MILE RAdiUs AND ALternative Time Windows.

\begin{tabular}{|c|c|c|c|c|c|}
\hline & $\begin{array}{c}1 \\
\text { Main }\end{array}$ & $\begin{array}{c}2 \\
0.25 \text { Mile }\end{array}$ & $\begin{array}{c}3 \\
1 \text { Year/1 Year }\end{array}$ & $\begin{array}{c}4 \\
6 \text { Months/6 Months }\end{array}$ & $\begin{array}{c}5 \\
\text { Hedonic }\end{array}$ \\
\hline \multicolumn{6}{|c|}{ Change in number of foreclosures within 0.1 mile... } \\
\hline \multirow[t]{2}{*}{ Single-family } & 0.004 & 0.000 & 0.000 & 0.002 & $-0.015^{*}$ \\
\hline & $(0.005)$ & $(0.003)$ & $(0.006)$ & $(0.007)$ & $(0.008)$ \\
\hline \multirow[t]{2}{*}{ Multifamily } & 0.005 & 0.000 & 0.000 & 0.000 & -0.004 \\
\hline & $(0.007)$ & $(0.002)$ & $(0.008)$ & $(0.012)$ & $(0.005)$ \\
\hline \multirow[t]{2}{*}{ Different association } & $-0.003^{* * *}$ & $-0.001^{*}$ & $-0.002^{*}$ & -0.003 & $-0.004^{*}$ \\
\hline & $(0.001)$ & $(0.001)$ & $(0.001)$ & $(0.002)$ & $(0.002)$ \\
\hline \multirow[t]{2}{*}{ SA 2 to 3} & $-0.087^{* * *}$ & $-0.084^{* * *}$ & $-0.063^{* *}$ & -0.079 & $-0.057^{* *}$ \\
\hline & $(0.028)$ & $(0.028)$ & $(0.027)$ & $(0.050)$ & $(0.028)$ \\
\hline \multirow[t]{2}{*}{$\mathrm{SA} 4$ to 12} & $-0.062^{* * *}$ & $-0.063^{* * *}$ & $-0.071^{* * *}$ & $-0.073^{* * *}$ & $-0.067^{* * *}$ \\
\hline & $(0.013)$ & $(0.013)$ & $(0.019)$ & $(0.025)$ & $(0.018)$ \\
\hline \multirow[t]{2}{*}{ SASA 13 to 50} & $-0.032^{* * *}$ & $-0.033^{* * *}$ & $-0.030^{* *}$ & $-0.048^{* * *}$ & $-0.041^{* * *}$ \\
\hline & $(0.008)$ & $(0.008)$ & $(0.012)$ & $(0.018)$ & $(0.010)$ \\
\hline \multirow[t]{2}{*}{ SADA 13 to 50} & -0.014 & -0.013 & $-0.024^{*}$ & -0.028 & -0.016 \\
\hline & $(0.013)$ & $(0.014)$ & $(0.012)$ & $(0.024)$ & $(0.015)$ \\
\hline \multirow[t]{2}{*}{ SASA $51+$} & $-0.015^{* * *}$ & $-0.015^{* * *}$ & $-0.013^{* *}$ & $-0.015^{*}$ & $-0.034^{*}$ \\
\hline & $(0.004)$ & $(0.004)$ & $(0.006)$ & $(0.008)$ & $(0.014)$ \\
\hline \multirow[t]{2}{*}{ SADA $51+$} & -0.002 & -0.002 & -0.001 & -0.001 & -0.012 \\
\hline & $(0.003)$ & $(0.002)$ & $(0.005)$ & $(0.007)$ & $(0.011)$ \\
\hline
\end{tabular}

\section{Controls}

Census tract-year

Experienced foreclosure dummy

Association size

Observations (repeat-sales pairs)

R-squared

$\begin{array}{ll}\checkmark & \checkmark \\ \checkmark & \checkmark \\ \checkmark & \checkmark\end{array}$

$\checkmark$

Source: Authors' calculations of Warren Group and City of Boston Assessing Department data. Note: ${ }^{* *}$, **, and ${ }^{*}$ represent statistical significance at 1, 5, and 10 percent levels, respectively. Model 1 is our main model from Table 4 . Model 2 expands the radius used in Model 1 from 0.1 mile to 0.25 mile. The following two models narrow the time window for "active" foreclosures from 2 years before the subject sale and 1 year after to 1 year before and after (Model 3 ) and 6 months before and after (Model 4). Model 5 is a hedonic version of the main specification. In Models 1-4, the predictors displayed represent the change in the number of foreclosures between the two sales. In the hedonic model, 5 , the predictors represent the level of foreclosures at the time of the single sale observation. In this model, the "experienced foreclosure" dummy is coded as one if there was a foreclosure sale in the three years prior to the arm's-length sale included in the sample. 


\section{References}

Anenberg, Eliot, and Edward Kung. 2013. "Estimates of the Size and Source of Price Declines Due to Nearby Foreclosures." Working paper. Federal Reserve Board.

Bailey, Martin J, Richard F Muth, and Hugh O Nourse. 1963. "A Regression Method for Real Estate Price Index Construction." Journal of the American Statistical Association 58(304): 933-942.

Barzel, Yoram, and Tim R. Sass. 1990. "The Allocation of Resources by Voting." The Quarterly Journal of Economics 105(3): 745-771.

Campbell, John Y., Stefano Giglio, and Parag Pathak. 2011. "Forced Sales and House Prices." American Economic Review 101(5): 2108-2131.

Coulson, N. Edward, and Lynn M. Fisher. 2014. "Houses, Apartments and Condos: The Governance of Multifamily Housing." Working paper.

Fisher, Lynn M., Lauren Lambie-Hanson, and Paul S. Willen. 2011. "A Profile of the Mortgage Crisis in a Low- and Moderate-Income Community." In Reinventing the American Mortgage System: Rethink, Recover, Rebuild., eds. Marvin Smith and Susan M. Wachter, 137-1588. Philadelphia: University of Pennsylvania Press.

Fisher, Lynn M., and Lauren S. Lambie-Hanson. 2012. "Are Investors the Bad Guys? Tenure and Neighborhood Stability in Chelsea, Massachusetts." Real Estate Economics 40(2): 351-386.

Foote, Christopher L., Kristopher Gerardi, and Paul S. Willen. 2008. "Negative Equity and Foreclosure: Theory and Evidence." The Journal of Urban Economics 64(2): 234-245.

Frame, Scott. 2010. "Estimating the Effect of Mortgage Foreclosures on Nearby Property Values: A Critical Review of the Literature." Economic Review 9(3): 1-9.

Genesove, David, and Christopher Mayer. 1997. "Equity and Time to Sale in the Real Estate Market." American Economic Review 87(3): 255-269.

Genesove, David, and Christopher Mayer. 2001. "Loss Aversion and Seller Behavior: Evidence from the Housing Market." The Quarterly Journal of Economics 116(4): 1233-1260. 
Gerardi, Kristopher, Eric Rosenblatt, Vincent Yao, and Paul Willen. 2012. "Foreclosure Externalities: Some New Evidence." Working paper.

Hansmann, Henry. 1991. "Condominium and Cooperative Housing: Transactional Efficiency, Tax Subsidies, and Tenure Choice." The Journal of Legal Studies 20(1): 25-71.

Harding, John P., Eric Rosenblatt, and Vincent W. Yao. 2009. "The Contagion Effect of Foreclosed Properties." Journal of Urban Economics 66(3): 164178.

Hartley, Daniel. 2011. "The Effect of Foreclosures on Nearby Housing Prices: Supply or Disamenity?" Working Paper 10-11R. Federal Reserve Bank of Cleveland.

Immergluck, Dan, and Geoff Smith. 2006. "The External Costs of Foreclosure: The Impact of Single-Family Mortgage Foreclosures on Property Values." Housing Policy Debate 17(1): 57-79.

Lambie-Hanson, Lauren. 2013. "When Does Delinquency Result in Neglect? Mortgage Distress and Property Maintenance." Public Policy Discussion Paper 13-1. Federal Reserve Bank of Boston.

Lasner, Matthew G. 2012. High Life: Condo Living in the Suburban Century. New Haven: Yale University Press.

Rossi-Hansberg, Esteban, Pierre-Daniel Sarte, and Raymond Owens III. 2010. "Housing Externalities." Journal of Political Economy 118(3).

Schuetz, Jenny, Vicki Been, and Ingrid Gould Ellen. 2008. "Neighborhood Effects of Concentrated Mortgage Foreclosures." Journal of Housing Economics 17(4): 306-319. 


\section{Appendix}

Table A-1: Robustness: Results for LARGe Associations OnLy.

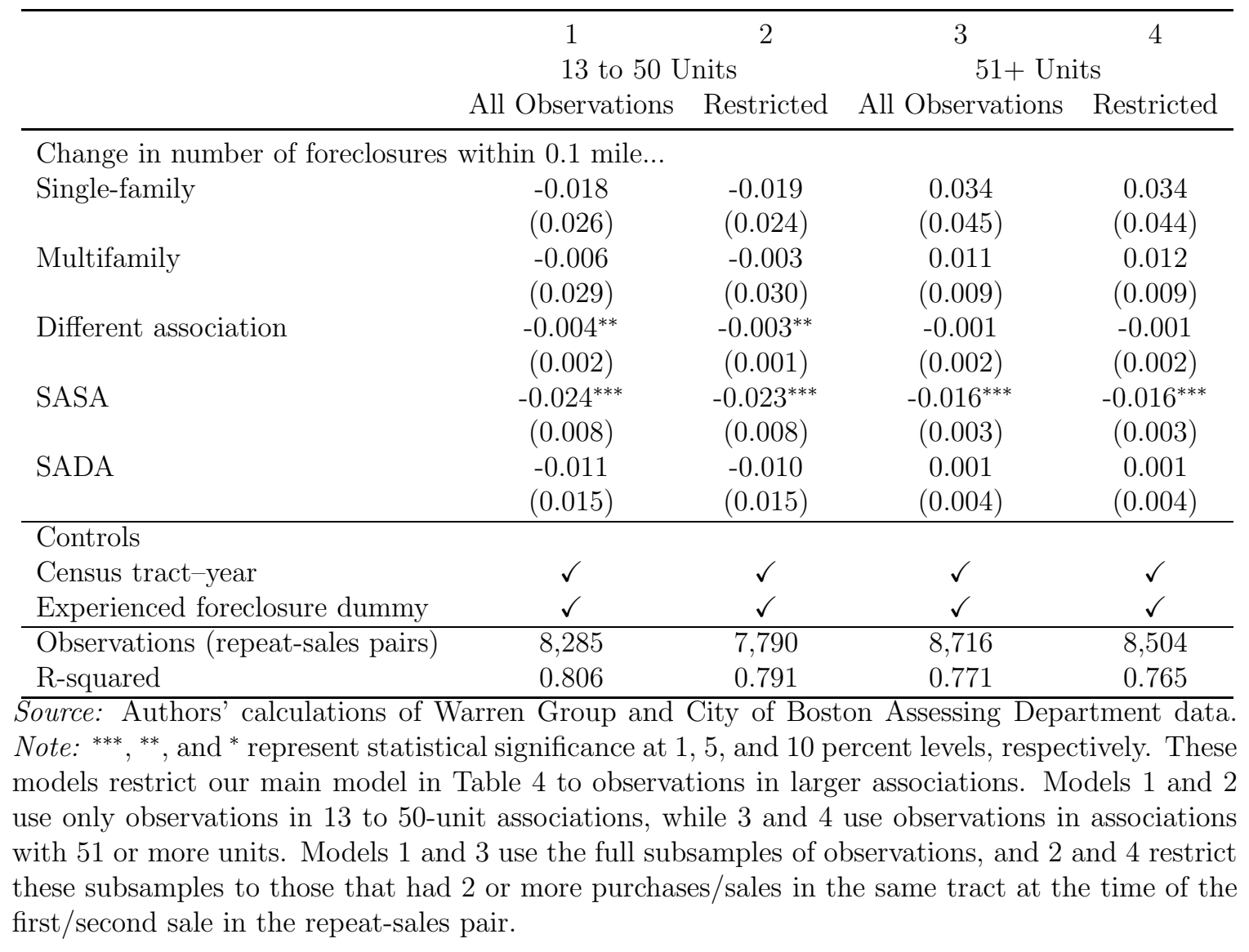

